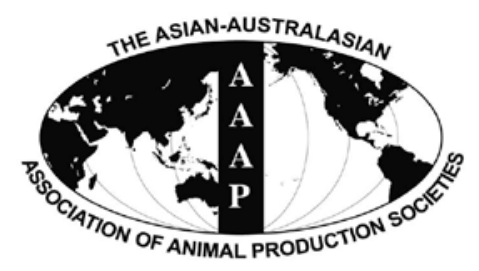

Asian-Aust. J. Anim. Sci.

Vol. 25, No. 2 : 163 - 169

February 2012

www.ajas.info

http://dx.doi.org/10.5713/ajas.2011.11168

\title{
Tissues Expression, Polymorphisms of IFN Regulatory Factor 6 (IRF6) Gene and Their Associated with Immune Traits in Three Pig Populations
}

\author{
Yang Liu, Jingeng Xu, Weixuan Fu, Ziqing Weng, Xiaoyan Niu, \\ Jianfeng Liu, Xiangdong Ding and Qin Zhang* \\ Key Laboratory of Animal Genetics Breeding and Reproduction, Ministry of Agriculture, \\ College of Animal Science and Technology, China Agricultural University, Beijing 100193, China
}

\begin{abstract}
Interferon regulatory factor 6 (IRF6) gene is a member of the IRF-family, and plays functionally diverse roles in the regulation of the immune system. In this report, the 13,720 bp porcine IRF6 genomic DNA structure was firstly identified with a putative IRF6 protein of 467 amino acids. Alignment and phylogenetic analysis of the porcine IRF6 amino acid sequences with their homologies to other species showed high identity (over 96\%). Tissues expression of IRF6 mRNA was observed by RT-PCR, the results revealed IRF6 expressed widely in eight tissues. One SNP (HQ026023:1383 G>C) in exon7 and two SNPs (HQ026023:130 G>A; 232 $\mathrm{C}>\mathrm{T}$ ) in the 5 promoter region of porcine IRF6 gene were demonstrated b y DNA sequencing analysis. A further analysis of SNP genotypes associated with immune traits including IFN- $\gamma$ and IL10 concentrations in serum was carried out in three pig populations including Large White, Landraces and Songliao Black pig (a Chinese indigenous breed). The results showed that the SNP (HQ026023:1383 G>C) was significantly associated with the level of IFN- $\gamma(\mathrm{d} 20)$ in serum $(\mathrm{p}=0.038$ ) and the ratio of IFN- $\gamma$ to IL10 (d 20) in serum ( $\mathrm{p}=0.041$ ); The other two SNPs (HQ026023:130 G>A; $232 \mathrm{C}>\mathrm{T}$ ) were highly significantly associated with IL10 level in serum both at the day $20(p=0.005 ; p=0.001)$ and the day $35(p=0.004 ; p=0.006)$. Identification of the porcine IRF6 gene will help our further understanding of the molecular basis of the IFN regulation pathway in the porcine immune response. All these results should indicate that the IRF6 gene can be regarded as a molecular marker associated with the IL10 level in serum and used for genetic selection in the pig breeding. (Key Words : Pig, IRF6, Expression, Polymorphisms, Association Analysis)
\end{abstract}

\section{INTRODUCTION}

The interferon regulatory factor (IRF) family of transcription factors was initially found to be involved in the induction of genes that encode type I IFN and as essential regulators of the activation of immune cells with the discovery of pattern recognition receptors (PRRs), which function as a 'platform' that links innate and adaptive immune response (Akira et al., 2006). The IRF gene family consists of nine members encoding transcription factors that share a highly conserved helix-turn-helix DNA-binding domain and a less conserved protein-binding domain. IRFs play important roles in immune response to viral infection, cytokine signaling, cell growth regulation and hematopoietic development (Nguyen et al., 1997; Honda et

\footnotetext{
* Corresponding Author : Qin Zhang. Tel: +86-10-62732634, Fax: +86-10-62732634, E-mail: qzhang@cau.edu.cn Received June 7, 2011; Accepted August 19, 2011
}

al., 2006) and most IRFs regulate the expression of IFN after viral infection. IRF6 gene is one of nine members of IRF-family and has been identified in human, mouse, and zebrafish (Kondo et al., 2002; Ben et al., 2005). Mutations in IRF6 cause Van der Woud syndromes (VWS) and Popliteal pterygium syndrome (PPS) has been reported for human (Lees et al., 2000; Kondo et al., 2002). However, the function of IRF6 remains unknown in pigs. In order to gain more knowledge of the porcine IRF6 gene regulating IFN involved in resistance to viral infection, we firstly identified the genomic structure of porcine IRF6 gene, and characterized its molecular organization, detected mRNA expression patterns and polymorphisms.

Cytokines are important mediators of the immune responses. The level of cytokines in serum such as IFN- $\gamma$ and IL10, vary with the organic state of health. IFN- $\gamma$ is critical for innate and adaptive immunity against viral and intracellular bacterial infections (Schoenborn and Wilson, 
2007). IL10 has pleiotropic effects on immunoregulation and inflammation, it down-regulates the expression of Th1 cytokines and MHC class II antigens (Redpath et al., 1999). Differences in levels of these immune traits and their ratios in serum among individuals under the same condition should provide evidence of genetic control. Considering the influences on IFN immune response and cytokines signaling pathway of IRFs genes, IRF6 could be an important candidate gene for porcine immune response and disease susceptibility, we also further performed an association analysis between the SNPs of the IRF6 gene and immune traits (IFN- $\gamma$, IL-10 and IFN- $\gamma / \mathrm{IL}-10$ ) in serum to estimate their possible effects in pigs.

\section{MATERIALS AND METHODS}

\section{Animal and tissue samples}

There are 3 pig breeds in our study, including Landrace, Large White and Songliao Black (a Chinese indigenous breed). They were sampled from the experimental farm of the Institute of Animal Sciences, Chinese Academy of Agricultural Sciences, Beijing, China. All pigs were vaccinated with (Classical Swine Fever, CSF) live vaccine at the age of $21 \mathrm{~d}$. The first blood samples were collected from each piglet one day before the vaccination (d 20), and 2 wk after the vaccination, the second blood samples were collected (d 35). Ear tissue samples of all pigs were also collected for DNA extraction. Nine different tissues, including heart, liver, spleen, lung, kidney, skeletal muscle, lymph node, brain and thymus, were collected from three 35-d-old Landrace pigs, then immediately frozen in liquid nitrogen and stored at $-80^{\circ} \mathrm{C}$ for spatial expression analysis.

\section{Measurement of serum IFN- $\gamma$ and IL-10 concentration}

Serum samples from three pig populations were stored at $-80^{\circ} \mathrm{C}$. A commercial ELISA kit (Biosource, Carlsbad, California) was used to measure the immune traits including IFN- $\gamma$ and IL-10 concentration in each serum sample based on the standard instructions from manufacturer. The kit contains a antibody coated 96-well test plate, standards of known IFN- $\gamma /$ IL10 concentrations, standard diluent buffer, wash buffers, and a biotin monoclonal antibody specific to IFN- $\gamma /$ IL10, a streptavidinHRP diluent solution and a stop solution. All samples were randomly placed in each plate and were used to calculate IFN- $\gamma$ and IL-10 concentrations based on a standard curve.

\section{Total RNA extraction and genomic DNA isolation}

The total RNA was extracted from different tissues with a TRIzol reagent (Invitrogen, USA). In order to prevent serious contamination of genomic DNA, DNaseI (Beijing Tiangen Biotechnology, China) treatment on the total RNA was carried out before first-strand cDNA synthesis. Genomic DNA was isolated from the ear tissue samples of Landrace, Large White and Songliao Black pigs using phenol/chloroform extraction and ethanol precipitation (Sambrook et al., 1989).

\section{RT-PCR analysis of IRF6 mRNA expression}

Based on the cloned mRNA sequence of IRF6 gene (GenBank Accession Number: AF327368), the reverse transcriptase-polymerase chain reaction amplification method was used to detect mRNA expression of the IRF6 gene. The first strand cDNA was synthesized in the presence of $2 \mu \mathrm{g}$ total RNA, $0.5 \mu \mathrm{M}$ oligo(dT)18, $200 \mu \mathrm{M}$ dNTPs, 10 U RNAsin (Promega, Madison, WI, USA), $1 \times$ M-MLV RT buffer, and $300 \mathrm{U}$ M-MLV reverse transcriptase (Promega, USA) in a volume of $50 \mu \mathrm{l}$ at $40^{\circ} \mathrm{C}$ for $1 \mathrm{~h}$. A specific primer setting for IRF6 gene mRNA expression analysis was designed to eliminate potential confounding results from genomic DNA contamination (Table 1). Another specific primer was also designed to amplify porcine house-keeping gene glyceraldehyde3phosphate dehydrogenase (GAPDH) mRNA (GenBank accession number: AF017079) as a positive control (GAPDH-F1 '5-TGAGACACGATGGTGAAGGT-3' and GAPDH-R1 5'-GGCATTGCTGATGATCTTGA-3').

\section{Genomic organization and SNP identification of the porcine IRF6 gene}

To characterize the genomic structure of the porcine IRF6 gene, the mRNA sequences of porcine IRF6 gene (GenBank Accession Number: AF327368) was used to search for porcine homologues with high throughput genomic sequences (HTGS) in the porcine genomic databases by BLAST (http://blast.ncbi.nlm.nih.gov) of NCBI GenBank database (http://www.ncbi.nlm.nih.gov/). One genomic DNA fragment (GenBank accession Number: AC167303.2) was obtained, which contains all introns and exons of the porcine IRF6 gene, and then the genomic organization was also subsequently deduced by experimental confirmation using exon-exon PCR across predicted introns or exon-intron PCR. Finally, the sequence of porcine IRF6 genomic DNA was submitted to NCBI GenBank database.

The porcine IRF6 gene consist of seven exons, using porcine genomic DNA, seven primer pairs were designed for PCR amplification of DNA sequences including all exon regions of the IRF6 gene (Table 1). The DNA from two pigs from each breed was selected for PCR amplification. All PCR fragments were purified with a Gel Extraction Mini Kit (Beijing Tiangen Biotechnology, China) and then sequenced. After comparing the sequences of obtained from the same PCR fragments from two Landrace, two Large 
Table 1. Primers used for mRNA expression and SNP detection of the porcine IRF6 gene

\begin{tabular}{|c|c|c|c|c|}
\hline Fragments & Primers sequence (5'-3') & Product size (bp) & PCR (Tm) & Used for \\
\hline IRF6-RT & $\begin{array}{l}\text { CTGAAGCCCTGGCTGGTAG } \\
\text { TGATGTTCAGGAAGGGGAAG }\end{array}$ & 436 & 60.6 & mRNA expression \\
\hline IRF6-1 & $\begin{array}{l}\text { TGAGGGAGCTGGAAAACAAC } \\
\text { CAGATCATGGCCСTCCAC }\end{array}$ & 228 & 60.2 & SNP detection \\
\hline IRF6-2 & $\begin{array}{l}\text { TTCGTAAGCGAGGCAATTTT } \\
\text { GGCAGTTTCCTGTCTTCCAG }\end{array}$ & 291 & 59.6 & SNP identification \\
\hline IRF6-3 & $\begin{array}{l}\text { TGATGTTCAGGAAGGGGAAG } \\
\text { AGGCCTGTGCATCTGTTTCT }\end{array}$ & 152 & 59.8 & SNP identification \\
\hline IRF6-4 & $\begin{array}{l}\text { GCAGAAGGTGGACAGGAAAT } \\
\text { GCTCACCCACATCCTTGTCT }\end{array}$ & 253 & 59.5 & SNP identification \\
\hline IRF6-5 & $\begin{array}{l}\text { CAGTTCCCACCATCCATCTT } \\
\text { TTCAGTACCGTGGGAAGGAG }\end{array}$ & 410 & 59.7 & SNP identification \\
\hline IRF6-6 & $\begin{array}{l}\text { AAGGCCAAGAGATGTTGACG } \\
\text { GATCTTATCGCCCACCAGAA }\end{array}$ & 156 & 60.0 & SNP identification \\
\hline IRF6-7 & $\begin{array}{l}\text { TGAAGTCATCAAGGCAGAGC } \\
\text { GTGGCGCGAATGATCTATG }\end{array}$ & 612 & 59.5 & SNP detection \\
\hline
\end{tabular}

White and two Songliao Black pigs using DNAMAN software (version 5.2.10, Lyn-non Biosoft, Canada), polymorphisms of IRF6 gene were found. Then all 302 samples from three pig populations were genotyped by directly sequencing of PCR products respectively.

\section{Association analysis}

In the end, we performed an association test between the genotypes of SNPs and three immune traits by SAS software (version 9.13), based on the following mixed model:

$$
y=X \beta+Z b+e
$$

Where $y$ is the vector of phenotype for immune traits analyzed; $\beta$ is the vector of fixed effects parameter including breed, ELISA plate effect and genotype effect, and $\mathrm{X}$ is its incidence matrix; $\mathrm{b}$ is the mixed vector of random component including sires effect and dam effect within sires, and $\mathrm{Z}$ is its incidence matrix; and e is the vector of residual effect.

\section{RESULTS AND DISSCUSSION}

\section{Sequence analysis of porcine IRF6 gene}

The porcine IRF6 cDNA is 2,203 bp in length (GenBank Accession Number: AF327368) and contains a 1,404 bp open reading frame (ORF) encoding a 467-amino acid polypeptide. Certainly, a polyadenylation stretch is at the $3^{\prime}$ end of the sequence, while a putative polyadenylation signal AATAAA is at 1,765 to 1,771 bp from it. The complete porcine IRF6 genomic DNA sequence spans 13,720 bp (GenBank Accession Number: HQ026023) and it consists of 6 introns separated by 7 exons (Figure 1). The intron/exon organization of porcine (6 introns and 7 exons) differs from that of human IRF6 (8 introns and 9 exons) and mouse IRF6 (7 introns and 8 exons) (Ben et al., 2005). These exons in coding region were also compared with that of human; but exon sizes of porcine IRF6 gene were not identical with that of human (Figure 1). All IRFs share a highly conserved helix-turn-helix DNA-binding domain (DBD) and a less conserved protein binding domain (Taniguchi et al., 2001). The DBD is defined by 5 tryptophan (W) residues which are separated by 10 to 18

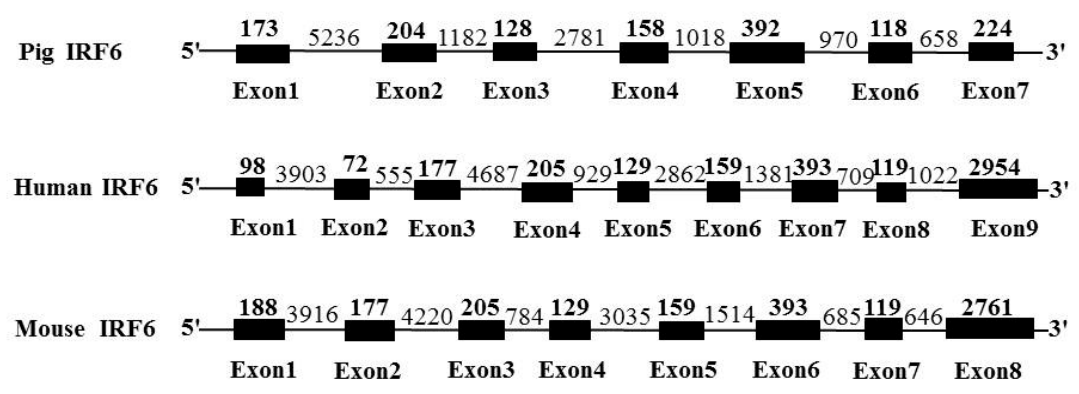

Figure 1. Genomic organization comparisons among pig, human and mouse IRF6 gene. Exon sequences are represented in the boxed areas (length in bases on top). 
amino acids respectively (Escalante et al., 1998; Liu et al., 2011). Through the DBD, IRFs bind to a core DNA sequence GAAA, termed interferon stimulating response element (ISRE) and IFN regulatory element (IRF-E) (Tanaka et al., 1993). The porcine IRF6 displayed a higher degree of homology than other known IRFs and also contain 5 tryptophan residues that are each separated by 1018 amino acids in the first 100 amino acids of the aminoterminal region, as well as a high sequence homology in their N-terminal region in DBD. In contrast, they showed very low homology in the C-terminal region. These sequence characters could contribute to further understanding of its functions in viral defense and immune regulation.

\section{Tissues expression of porcine IRF6 gene}

To determine tissue distribution of the porcine IRF6 gene, reverse transcription quantitative PCR (RT-PCR) was applied to nine different tissue samples. Results showed that the mRNA of IRF6 was expressed in all analyzed tissues except spleen (Figure 2). The expression levels of IRF6 detected in lung, liver and lymph node were higher, comparatively, while in brain and heart the levels were lower. We did not find any expression of the IRF6 gene in the spleen. In some previous studies, IRF6 gene of Xenopus was found to be expressed as a maternal transcript and later in the posterior somite mesoderm of neural groove stage embryos, and IRF6 expression has been observed only in the ovary after adulthood was attained (Hatada et al., 1997). Moreover, Kondo et al. (2002) detected the expression of the mouse IRF2 mRNA in several tissues by RT-PCR and also found higher expression levels in lung, liver and much lower expression levels in brain, heart, which is consistent with our results in pigs.

\section{Polymorphisms detection of porcine IRF6 gene}

Sequence comparisons of the same PCR fragment among three pig populations detected one SNP (HQ026023:1383 G>C) in exon7 and two SNPs (HQ026023:130 G>A; $232 \mathrm{C}>\mathrm{T}$ ) in the 5 promoter region of the porcine IRF6 gene. The three SNPs are all synonymous mutations, and do not induce a substitution of

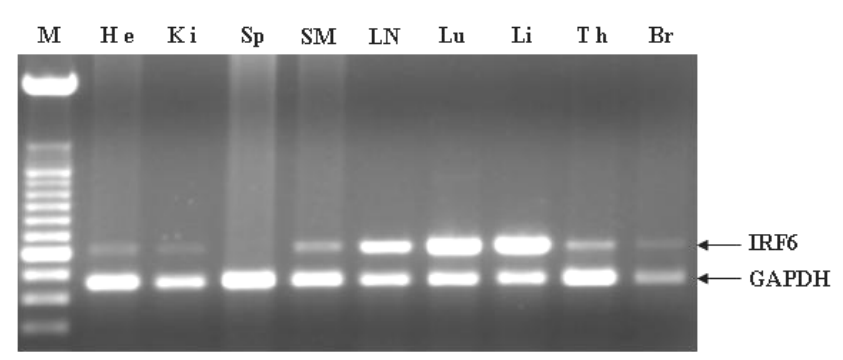

Figure 2. mRNA expression of porcine IRF6 gene was detected in different tissues by RT-PCR. He, heart; Ki, kidney; Sp, spleen; SM, skeletal muscle; LN, lymph node; Lu, lung; Li, liver; Th, thymus; Br, brain; M, 100 bp DNA marker.

amino acids. The three SNPs were genotyped by directly sequencing of the PCR products of all 302 pigs. The genotypes and allele frequencies of the identified SNPs in three different pig populations were presented in Table 2. For two SNPs in 5' promoter region (HQ026023:130 G>A and HQ026023:232 C>T), the allele $G$ and $C$ have higher frequencies than allele $\mathrm{A}$ and $\mathrm{T}$ in Large White and Songliao Black pig populations, but have lower allele frequencies in Landrace population. In addition, for the SNP ((HQ026023:1383 G>C), the allele G had higher allele frequencies, while there was only genotype GG in Chinese indigenous breed Songliao Black pig population.

\section{Association analysis of porcine IRF6 gene in three pig populations}

Based on the aforementioned work, we performed association analysis to confirm whether the identified SNPs in the breeds have a relationship with immune traits. Results showed that all the traits among three breeds were significantly different except for the ratio of IFN- $\gamma$ to IL10 (d 35) in serum $(\mathrm{p}<0.05)$ (Table 3). The serum IFN- $\gamma$ level (d 20; d 35) of Landrace was significantly higher than Large White and Songliao Black (Table 3); In contrast, Songliao Black had a significantly higher serum IL10 level (day 20; day 35) than Large White and Landrace $(\mathrm{p}<0.01)$ (Table 3); The ratio of IFN- $\gamma$ to IL10 (d 20) in serum of Songliao Black was significantly lower than Landrace and Large White $(\mathrm{p}<0.05)$ (Table 3$)$. As reported in a previous study, the capacity to activate or inhibit monocytic and $\mathrm{T}$ lymphocytic functions could be reflected by the ratio of

Table 2. Genotype and allele frequencies of the SNPs detected in the porcine IRF6 gene ${ }^{1}$

\begin{tabular}{|c|c|c|c|c|c|c|c|c|c|c|c|c|c|c|c|}
\hline \multirow{3}{*}{ Breed } & \multicolumn{5}{|c|}{ HQ026023:g.130 G>A } & \multicolumn{5}{|c|}{ HQ026023:g. 232 C>T } & \multicolumn{5}{|c|}{ HQ026023:g. 1383 G>C } \\
\hline & \multicolumn{3}{|c|}{$\begin{array}{l}\text { Genotype } \\
\text { frequencies }\end{array}$} & \multicolumn{2}{|c|}{$\begin{array}{c}\text { Allele } \\
\text { frequencies }\end{array}$} & \multicolumn{3}{|c|}{$\begin{array}{l}\text { Genotype } \\
\text { frequencies }\end{array}$} & \multicolumn{2}{|c|}{$\begin{array}{c}\text { Allele } \\
\text { frequencies }\end{array}$} & \multicolumn{3}{|c|}{$\begin{array}{l}\text { Genotype } \\
\text { frequencies }\end{array}$} & \multicolumn{2}{|c|}{$\begin{array}{c}\text { Allele } \\
\text { frequencies }\end{array}$} \\
\hline & GG & GA & AA & $\mathrm{G}$ & $\mathrm{A}$ & $\mathrm{CC}$ & $\mathrm{CT}$ & $\mathrm{TT}$ & $\mathrm{C}$ & $\mathrm{T}$ & $\mathrm{GG}$ & GC & $\mathrm{CC}$ & $\mathrm{G}$ & $\mathrm{C}$ \\
\hline Landrace (68) & 0.25 & 0.37 & 0.38 & 0.44 & 0.56 & 0.25 & 0.37 & 0.38 & 0.44 & 0.56 & 0.84 & 0.16 & 0 & 0.92 & 0.08 \\
\hline Large White (163) & 0.31 & 0.44 & 0.25 & 0.53 & 0.47 & 0.28 & 0.47 & 0.25 & 0.52 & 0.48 & 0.40 & 0.41 & 0.19 & 0.61 & 0.39 \\
\hline Songliao Black (71) & 0.32 & 0.58 & 0.10 & 0.61 & 0.39 & 0.31 & 0.56 & 0.13 & 0.59 & 0.41 & 1.00 & 0.00 & 0.00 & 1.00 & 0.00 \\
\hline
\end{tabular}

The number of animals in each breed is indicated between parentheses. 
Table 3. Association analysis of immune traits in three pig breeds

\begin{tabular}{|c|c|c|c|}
\hline \multirow[b]{2}{*}{ Traits } & \multicolumn{3}{|c|}{ Breeds (Least square mean \pm SE) } \\
\hline & $\begin{array}{l}\text { Landrace } \\
(\mathrm{n}=68)\end{array}$ & $\begin{array}{l}\text { Large White } \\
(\mathrm{n}=163)\end{array}$ & $\begin{array}{l}\text { Songliao Black } \\
\quad(\mathrm{n}=71)\end{array}$ \\
\hline $\mathrm{IFN}-\gamma(\mathrm{d} 20)$ & $107.57 \pm 12.61^{\mathrm{A}}$ & $58.29 \pm 12.98^{\mathrm{B}}$ & $59.86 \pm 13.85^{\mathrm{B}}$ \\
\hline IFN- $\gamma(\mathrm{d} 35)$ & $100.47 \pm 15.64^{\mathrm{A}}$ & $59.52 \pm 16.10^{\mathrm{B}}$ & $66.50 \pm 17.17^{\mathrm{B}}$ \\
\hline IFN- $\gamma / \mathrm{IL} 10$ (d 20) & $1.53 \pm 0.47^{\mathrm{a}}$ & $1.32 \pm 0.49^{\mathrm{b}}$ & $0.66 \pm 0.52^{\mathrm{b}}$ \\
\hline IL10 (d 20) & $133.62 \pm 41.29^{\mathrm{A}}$ & $81.82 \pm 42.49^{\mathrm{A}}$ & $173.74 \pm 45.32^{\mathrm{B}}$ \\
\hline IL10 (d 35) & $100.39 \pm 33.50^{\mathrm{a}}$ & $54.38 \pm 34.48^{\mathrm{b}}$ & $107.21 \pm 36.78^{\mathrm{a}}$ \\
\hline IFN- $\gamma / \mathrm{IL} 10$ (d 35) & $2.152 \pm 0.45$ & $1.91 \pm 0.46$ & $1.65 \pm 0.50$ \\
\hline
\end{tabular}

${ }^{\text {a. b }}$ Statistically different of least square means $(p<0.05){ }^{\text {A.B }}$ Statistically different of least square means $(p<0.01)$.

IFN- $\gamma /$ IL-10 production, and a higher ratio has also been shown to have relevance with depressive disorders (Maes, 1999). In our study, the ratio of IFN- $\gamma$ to IL-10 in Songliao Black pig was lower, which could be explained as the Chinese indigenous breed has a better $\mathrm{T}$ lymphocytic balance and immune capacity than other two western commercial pig breeds in our study. Besides, the results also indicate that genetic background is one of the important factors that influence the immune capacity.

On the other hand, the results of association analysis between SNPs and immune traits also showed that the SNP (HQ026023:1383 G>C) of IRF6 gene was significantly associated with the level of IFN- $\gamma$ (d 20) in serum (p = 0.038 ) and the ratio of IFN- $\gamma$ to IL10 (d 20) in serum ( $\mathrm{p}=$ 0.041) (Table 4). The other two SNPs (HQ026023:130 $\mathrm{G}>\mathrm{A} ; 232 \mathrm{C}>\mathrm{T}$ ) were highly significantly associated with IL10 level in serum both at the $d 20(p=0.005 ; p=0.001)$ and the day 35 ( $p=0.004 ; p=0.006$ ) (Table 4). In the further analysis, for the SNP (HQ026023:1383 G>C), the IFN- $\gamma$ level in serum of pigs associated with genotype GG were significantly higher than with genotype CC $(\mathrm{p}<0.05)$; but the ratio of IFN- $\gamma$ to IL10 with genotype CC was significantly higher than those with genotype $G G(p<0.05)$. For the other two SNP (HQ026023:130 G>A; $232 \mathrm{C}>\mathrm{T}$ ),

Table 4. Association analysis and multiple tests of the IRF6 gene SNPs with immune traits in three pig populations

\begin{tabular}{|c|c|c|c|c|c|c|}
\hline \multirow[b]{2}{*}{ Immune traits } & \multicolumn{3}{|c|}{$\mathrm{p}$-value } & \multirow{2}{*}{\multicolumn{3}{|c|}{$\begin{array}{c}\text { Polymorphism genotypes } \\
\text { (Least square mean } \pm \text { SE) }\end{array}$}} \\
\hline & HQ026023 & HQ026023 & HQ026023 & & & \\
\hline \multirow{2}{*}{$\begin{array}{l}\text { IFN- } \gamma \\
(\mathrm{d} 20)\end{array}$} & 0.190 & 0.216 & $0.038 *$ & \multicolumn{3}{|c|}{ HQ026023:g.1383 G>C } \\
\hline & & & & $\begin{array}{c}\text { GG } \\
44.59 \pm 26.18^{\text {a }}\end{array}$ & $\begin{array}{c}\text { GC } \\
34.08 \pm 26.45^{b}\end{array}$ & $\begin{array}{c}\text { CC } \\
33.87 \pm 26.64^{b}\end{array}$ \\
\hline $\begin{array}{l}\text { IFN- } \gamma \\
\text { (d 35) }\end{array}$ & 0.841 & 0.941 & 0.389 & & & \\
\hline \multirow{2}{*}{$\begin{array}{l}\text { IFN- } \gamma / \mathrm{IL} 10 \\
(\mathrm{~d} 20)\end{array}$} & 0.616 & 0.703 & $0.041^{*}$ & \multicolumn{3}{|c|}{ HQ026023:g.1383 G>C } \\
\hline & & & & $\begin{array}{c}\text { GG } \\
0.89 \pm 0.56^{\text {a }}\end{array}$ & $\begin{array}{c}\text { GC } \\
0.90 \pm 0.47^{\text {a }}\end{array}$ & $\begin{array}{c}\text { CC } \\
1.08 \pm 0.34^{\mathrm{b}}\end{array}$ \\
\hline \multirow{4}{*}{$\begin{array}{l}\text { IL10 } \\
\text { (d 20) }\end{array}$} & $0.005 * *$ & $0.001 * *$ & 0.317 & \multicolumn{3}{|c|}{ HQ026023:g.130 G>A } \\
\hline & & & & $\begin{array}{c}\text { GG } \\
349.58 \pm 52.54^{\mathrm{A}}\end{array}$ & $\begin{array}{c}\text { GA } \\
200.12 \pm 70.06^{B}\end{array}$ & $\begin{array}{c}\text { AA } \\
138.93 \pm 99.99^{\mathrm{B}}\end{array}$ \\
\hline & & & & \multicolumn{3}{|c|}{ HQ026023:g.232 C>T } \\
\hline & & & & $\begin{array}{c}\text { CC } \\
76.89 \pm 57.65^{\mathrm{A}}\end{array}$ & $\begin{array}{c}\text { CT } \\
81.44 \pm 69.56^{\mathrm{A}}\end{array}$ & $\begin{array}{c}\text { TT } \\
406.23 \pm 95.59^{\mathrm{B}}\end{array}$ \\
\hline \multirow{4}{*}{$\begin{array}{l}\text { IL10 } \\
\text { (d 35) }\end{array}$} & $0.004 * *$ & $0.006 * *$ & 0.819 & \multicolumn{3}{|c|}{ HQ026023:g.130 G>A } \\
\hline & & & & $\begin{array}{c}\text { GG } \\
279.01 \pm 42.50^{\mathrm{A}}\end{array}$ & $\begin{array}{c}\text { GA } \\
162.64 \pm 56.67^{\mathrm{B}}\end{array}$ & $\begin{array}{c}\text { AA } \\
72.33 \pm 80.88^{\text {B }}\end{array}$ \\
\hline & & & & \multicolumn{3}{|c|}{ HQ026023:g.232 C>T } \\
\hline & & & & $\begin{array}{c}\text { CC } \\
12.29 \pm 46.63^{\mathrm{A}}\end{array}$ & $\begin{array}{c}\mathrm{CT} \\
55.41 \pm 56.27^{\mathrm{A}}\end{array}$ & $\begin{array}{c}\text { TT } \\
326.19 \pm 77.32^{\mathrm{B}}\end{array}$ \\
\hline $\begin{array}{l}\text { IFN- } \gamma / \text { IL10 } \\
\text { (d 35) }\end{array}$ & 0.280 & 0.320 & 0.643 & & & \\
\hline
\end{tabular}

${ }^{*} \mathrm{p}<0.05 ;{ }^{* *} \mathrm{p}<0.01{ }^{\text {a. b }}$ Statistically different of least square means $(\mathrm{p}<0.05){ }^{\text {A.B }}$ Statistically different of least square means $(\mathrm{p}<0.01)$. 
the IL10 level in serum of pigs associated with genotype GG and TT were significantly higher than those with genotype AA and CC $(\mathrm{p}<0.01)$.

IRF6 plays an important role in initiating cellular interferon-stimulated gene-mediated antiviral responses and in the transforming growth factor- $\beta$ signaling pathway. Moreover, in human, this gene is essential for the development of the lip and palate and involved in the development of the skin and external genitalia. Mutations in IRF6 gene are pathogenic for both Van der Woud syndromes (VWS) and Popliteal pterygium syndrome (PPS) (Kondo et al., 2002). Until now, two missense mutations in the IRF6 gene had been identified in two Japanese families with PPS (Matsuzawa et al., 2010). Another two novel mutations which may affect splicing in the IRF6 gene associated with VWS were also reported by Scioletti et al. (2010). In the pig, another IFN regulatory factor (IRF1) has been reported to be significantly associated with cytokine traits (Liu et al., 2010; 2011). The SNP (HQ026023:1383 $\mathrm{G}>\mathrm{C}$ ) in exon7 and two SNPs (HQ026023:130 G>A; 232 $\mathrm{C}>\mathrm{T}$ ) in $5^{\prime}$ promoter region of IRF6 were not missense mutations or induced amino acid substitution. However, the synonymous SNPs can also affect protein expression by alteration or by increasing the stability of the mRNA (Capon et al., 2004). Additionally, a “silent” polymorphism changes substrate specificity (Kimchi-Sarfaty et al., 2007). Furthermore, it is known that mutations in the promoter region are involved in biological processes such as transcriptional and posttranscriptional control of gene expression (Nakaya et al., 2007).

As the immune system plays an essential role in disease resistance of animals, genes involved in the response of immune system could be regarded as the candidate genes for selection. Our results provided a straightforward insight that the IRF6 gene which has effects on serum IFN- $\gamma$, IL-10 level and ratio of IFN- $\gamma$ to IL-10 in serum could served as a genetic marker for immune traits. But the number of pigs analyzed in our study was restricted, further investigations are needed to confirm the relationships between the SNPs with immune traits among other pig populations.

In summary, the 13,720 bp-length IRF6 genomic organization with seven exons and six introns was identified. The result of mRNA expression revealed that the porcine IRF6 gene was expressed widely in lung, liver, lymph node, brain, kidney, skeletal muscle, thymus and heart but not in the spleen. One SNP (HQ026023:1383 G>C) in exon 7 and two SNPs (HQ026023:130 G>A; $232 \mathrm{C}>\mathrm{T}$ ) in 5' promoter region of IRF6 gene were found. Further association analysis showed that the three SNPs were highly significantly associated with serum IFN- $\gamma$ (d 20), ratio of IFN- $\gamma /$ IL10 (d 20) and IL10 level (d 20; d 35) respectively. The results indicated that IRF6 gene could be regarded as a genetic marker with effects on these immune traits in porcine disease resistance breeding.

\section{ACKNOWLEDGEMENTS}

The work was supported by the National Major Special Project of China on New Varieties Cultivation for Transgenic Organisms (Grand No. 2009ZX08009-146B) and China Postdoctoral Science Foundation Funded Project (Grand No. 20100470412).

\section{REFERENCES}

Akira, S., S. Uematsu and O. Takeuchi. 2006. Pathogen recognition and innate immunity. Cell 124:783-801.

Ben, J., E. W. Jabs and S. S. Chong. 2005. Genomic, cDNA and embryonic expression analysis of zebrafish IRF6, the gene mutated in the human oral clefting disorders Van der Woude and popliteal pterygium syndromes. Gene Expr. Patterns 5:629-638.

Capon, F., M. H. Allen, M. Ameen, A. D. Burden, D. Tillman, J. N. Barkerand and R. C. Trembath. 2004. A synonymous SNP of the corneodesmosin gene leads to increased mRNA stability and demonstrates association with psoriasis across diverse ethnic groups. Hum. Mol. Genet. 13:2361-2368.

Escalante, C. R., J. Yie, D. Thanos and A. K. Aggarwal. 1998. Structure of IRF-1 with bound DNA reveals determinants of interferon regulation. Nature 391:103-106.

Hatada, S., M. Kinoshita, S. Takahashi, R. Nishihara, H. Sakumoto, A. Fukui M. Noda and M. Asashima. 1997. An interferon regulatory factor-related gene (xIRF-6) is expressed in the posterior mesoderm during the early development of Xenopus laevis. Gene 203:183-188.

Honda, K. and T. Taniguchi. 2006. IRFs: master regulators of signaling by Toll-like receptors and cytosolic patternrecognition receptors. Nat. Rev. Immunol. 6:644-658.

Kimchi-Sarfaty, C., J. M. Oh, I. W. Kim, Z. E. Sauna, A. M. Calcagno, S. V. Ambudkar and M. M. Gottesman. 2007. A "silent" polymorphism in the MDR1 gene changes substrate specificity. Science 315:525-528.

Kondo, S., B. C. Schutte, R. J. Richardson, B. C. Bjork, A. S. Knight, Y. Watanabe, E. Howard, R. L. de Lima, S. DaackHirsch, A. Sander, D. M. McDonald-McGinn, E. H. Zackai, E. J. Lammer, A. S. Aylsworth, H. H. Ardinger, A. C. Lidral, B. R. Pober, L. Moreno, M. Arcos-Burgos, C. Valencia, C. Houdayer, M. Bahuau, D. Moretti-Ferreira, A. Richieri-Costa, M. J. Dixon and J. C. Murray. 2002. Mutations in IRF6 cause Van der Woude and popliteal pterygium syndromes. Nat. Genet. 32: 285-289.

Lees, M. M., R. M. Winter, S. Malcolm, H. M. Saal and L. Chitty. 1999. Popliteal pterygium syndrome: a clinical study of three families and report of linkage to the Van der Woude syndrome locus on 1q32. J. Med. Genet. 36:888-892.

Liu, Y., X. Lu, Y. R. Luo, J. P. Zhou, X. Y. Liu, Q. Zhang and Z. J. Yin. 2010. Effect of single nucleotide polymorphism of IRF1 gene on cytokine traits in three pig breeds. J. Anim. Vet. Adv. 9(18):2346-2350.

Liu, Y., X. Lu, Y. R. Luo, J. P. Zhou, X. Y. Liu, J. F. Liu, X. D. 
Ding and Q. Zhang. 2011. Molecular characterization and association analysis of porcine interferon regulatory factor 1 gene. Mol. Biol. Rep. 38:1901-1907.

Matsuzawa, N., S. Kondo, K. Shimozato, T. Nagao, M. Nakano, M. Tsuda, A. Hirano, N. Niikawa and K. Yoshiura. 2010. Two missense mutations of the IRF6 gene in two Japanese families with popliteal pterygium syndrome. Am. J. Med. Genet. A. 152: 2262-2267.

Nakaya, H. L., P. P. Amaral, R. Louro, A. Lopes, A. A. Fachel, Y. B. Morira, T. A. El-Jundi, A. M. da Silva, E. M. Reis and S. Verjovski-Almeida. 2007. Genome mapping and expression analysis of human intronic noncoding RNAs reveal tissuespecific patterns and enrichment in genes related to regulation of transcription. Genome Biol. 8, R43.

Nguyen, H., J. Hiscott and P. M. Pitha. 1997. The growing family of interferon regulatory factors. Cytokine Growth Factor Rev. 8:293-312.

Redpath, S., A. Angulo, N. R. J. Gascoigne and P. Ghazal. 1999. Murine cytomegalovirus infection down-regulates MHC class II expression on macrophages by induction of IL10. J. Immunol. 162:6701-6707.
Sambrook, J., E. F. Fritsch and T. Maniatis. 1989. Molecular cloning: a laboratory manual, 2nd edn. Cold Spring Harbor Laboratory Press, New York.

Schoenborn, J. R. and C. B. Wilson. 2007. Regulation of interferon-gamma during innate and adaptive immune responses. Adv. Immunol. 96:41-101.

Scioletti, A.P., F. Brancati, V. Gatta, I. Antonucci, B. Peissel, A. Pizzuti, C. Mortellaro, S. Tetè, E. Gherlone, G. Palka and L. Stuppia. 2010. Two novel mutations affecting splicing in the IRF6 gene associated with van der Woude syndrome. J. Craniofac. Surg. 21:1654-1656.

Tanaka, N., T. Kawakami and T. Taniguchi. 1993. Recognition DNA sequences of interferon regulatory factor 1 (IRF-1) and IRF-2, regulators of cell growth and the interferon system. Mol. Cell Biol. 13:4531-4538.

Taniguchi, T., K. Ogasawara, A. Takaoka and N. Tanaka. 2001. IRF family of transcription factors as regulators of host defense. Annu. Rev. Immunol. 19:623-655. 